\title{
Šport ako možnost' inklúzie osôb so zdravotným znevýhodnením
}

\section{Sport as a Possibility of Inclusion of People with Disabilities}

Erika Štangová1, Fakulta sociálnych vied UCM v Trnave, Trnava

\section{Abstrakt}

Východiská: Príspevok sa zaoberá športom ako jednej z popredných foriem inklúzie osôb so zdravotným znevýhodnením. Športová činnost' vytvára osobám so zdravotným znevýhodnením priestor na stretávanie, vymieňanie skúseností, tvorbu sociálnych kontaktov, ale taktiež sa učia vyrovnávat's prekážkami, s ktorými sa počas života.

Ciel'om príspevku bolo zistit', či šport prispieva k inklúzii osôb so zdravotným znevǵhodnením.

Metodika: V príspevku prezentujeme výsledky pilotnej fázy nášho kvalitatívneho výskumu, v rámci ktorého sme použili metódu pološtrukturovaného rozhovoru.

\section{Kl'účové slová}

šport, sociálna inklúzia, osoby so zdravotným znevýhodnením

\section{Abstract}

Background: The paper deals with sport as one of the leading forms of inclusion of people with disabilities. Sports activities create a space for people with disabilities to meet, exchange experiences, create social contacts, but they also learn to cope with the obstacles they face during their lives.

The aim of the paper was to find out whether sport contributes to the inclusion of people with disabilities.

Methodology: In this paper we present the results of the pilot phase of our qualitative research, in which we used the method of semi-structured interview.

\section{Keywords}

sport, social inclusion, people with disabilities

\section{Úvod}

Príspevok sa venuje športu ako jednej z popredných foriem sociálnej inklúzie osôb so zdravotným znevýhodnením. Športovú činnost' môžeme považovat' za jeden z najvýraznejších fenoménov v spoločnosti, ktorý napomáha k udržaniu nie len telesnej, ale aj duševnej zdatnosti a často sa stáva novým životným štýlom človeka so zdravotným znevýhodnením. Sportová činnost' nemá pozitívne účinky len na fyzickú stránku človeka, ale má výrazný podiel na zvyšovaní mieri samostatnosti, budovanie sociálnych zručností a interakcii. Zastáva významné miesto v procese začleňovania človeka do spoločnosti. Považujeme za dôležité venovat' viac pozornosti problematike športu, ako významného prostriedku socializácie l'udí so zdravotným znevýhodnením do spoločnosti. 


\section{Súčasný stav poznania}

Medzi jednu z popredných foriem inklúzie osôb so zdravotným znevýhodnením do spoločnosti môžeme považovat práve športovú činnost'. Ak sa na problematiku športu osôb so zdravotným znevýhodnením bližšie pozrieme cez skúsenost' odborníkov môžeme si dovolit' konštatovat', že priaznivé účinky sú výraznejšie ako u intaktnej časti populácie. Jedným z ukazovatelov je práve zlepšenie fyzickej zdatnosti, ktoré nastalo vd'aka športovej a pohybovej aktivite. Toto zlepšenie ovplyvňuje stupeň mobility, sebaobsluhy a taktiež stabilizáciu zdravotného stavu. Medzi dalšś pozitívny účinok športovej činnosti je práve zlepšenie celkovej imunity človeka, čím sa človek so zdravotným znevýhodnením stáva odolnejší voči rôznym vírusom, infekciám či vírusom. Práve šport môžeme vd’aka svojím pozitívnym účinkom považovat'za jednu z najúčinnejších foriem inklúzie osôb do spoločnosti, nakol'ko má výrazný pozitívny vplyv na duševnú pohodu a sociálne väzby človeka so zdravotným znevýhodnením (Qi, Jing, Ha Amy, 2012, McConkey, 2019, Haudenhuyse, 2017, Tacon, 2017). Práve prostredníctvom športovej činnosti majú ludia so zdravotným znevýhodnením možnost' nadväzovat' a budovat' sociálne kontakty. Hall, Lindzey (1997) považuje za najdôležitejšie vzt́ahy vytvorené v rámci športového procesu práve vzt́ahy medzi športovcami navzájom, športovcom a rodinou, športovcom a trénerom, športovcom a jeho osobným asistentom, ale aj športovcom a jeho sociálnym okolím.

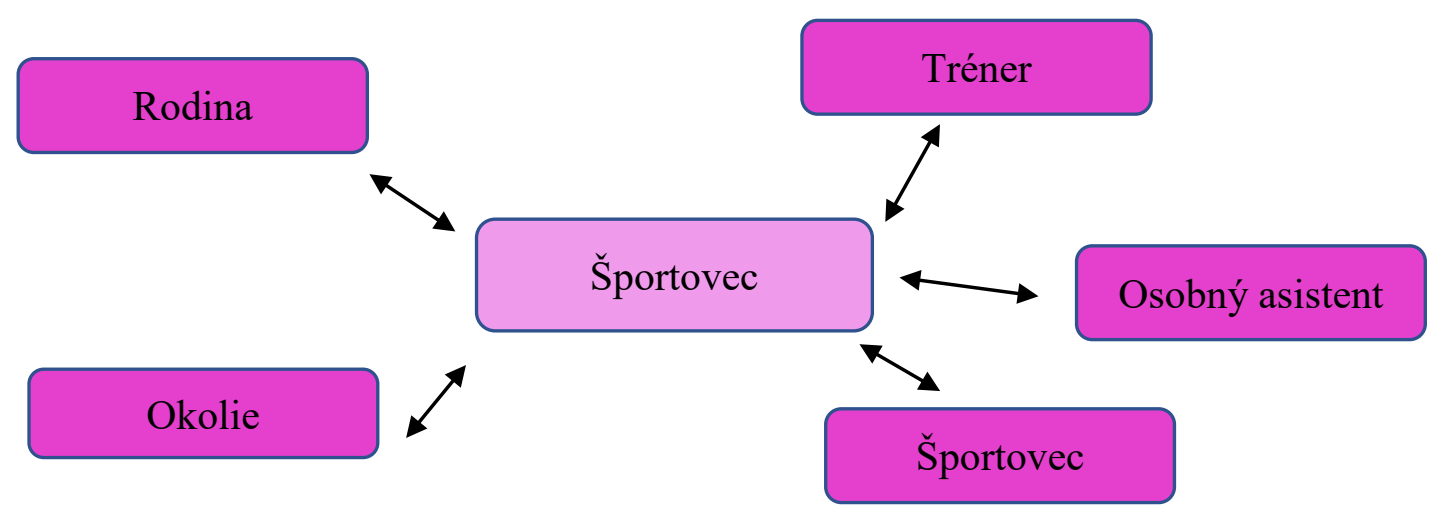

Graf. 1 Interakčné procesy v športe (Zdroj: Vlastný - upravené podla Hall, Lindzey (1997)

Vo svete, ale aj na Slovensku môžeme pozorovat zvýšený záujem o problematiku športu osôb so zdravotným znevýhodnením. V posledných rokoch stúpa počet športových klubov a športovísk, kde môžu ludia so zdravotným znevýhodnením trávit' svoj volný čas a rozvíjat' svoje schopnosti. Za najoblúbenejšie kluby a športy môžeme zaradit práve bocciu, lukostrel'bu, triatlon, plávanie, športovú strel'bu a basketbal na invalidnom vozíku a samozrejme mnohé iné. Športová činnosté dosahuje vysokú úroveň a športovci dosahujú obdivuhodné výsledky (Choutka, Dovalil, 2004). Ako uvádza Magee (2018) športová činnost' prispieva k úspešnej inklúzii osôb so zdravotným znevýhodnením do spoločnosti. Prostredníctvom športovej činnosti prichádza k formovaniu osobnosti a taktiež prispieva k rozvíjaniu dôležitých hodnôt ako sú empatia, kolektívnost', solidarita a princíp fair play hry. Sportovú činnost' môžeme podla Sekotu (2007) označit' za hru, pri ktorej prichádza k spojeniu kreativity, spontánnosti, ale aj nepredvídatel'nosti. Človek so zdravotným znevýhodnením je vd’aka športu vytrhnutý z každodenných stereotypov. Prostredníctvom športovej činnosti prichádza k ovplyvňovaniu všetkých sociálnych úloh.

Významu športu pri integrácii osôb so zdravotným znevýhodnením sa venovali aj Kitchin a Howe (2014) vo Vel'kej Británii. Vo svojom výskume skúmali, či šport môžeme považovat' za účinný prostriedok začleňovania osôb so zdravotným znevýhodnením do spoločnosti, pričom zistili, že integrácia v pravom zmysle slova ešte stále nie je realizovaná.

Autori Hrouda a Rybová (2010) vymedzili určité resocializačné a rehabilitačné účinky športovej činnosti, ktoré vyjadrili v tzv. uzlových bodoch. $V$ daných uzlových bodoch môžeme pozorovat' premenu zo životnej dráhy žitia človeka na dráhu športovo-životnú. Ako však poznamenali, motivácia k športovej činnosti sa mení a je závislá najmä od fáz života.

Na základe súčasného stavu poznania sme si sformulovali výskumnú otázku. Hlavná výskumná otázka znie: „Prispieva šport k inklúzií osôb so zdravotným znevýhodnením?“. 


\section{Metódy}

Výskum sme realizovali v kvalitatívnom dizajne, pričom metódu zberu dát sme si zvolili pološtrukturovaný rozhovor. Náš výskum sme plánovali realizovat’ s osobami so zdravotným znevýhodnením, ktoré sa aktívne venujú športovej činnosti. Realizáciu rozhovorov s piatimi respondentami sme chápali ako súčast' výskumu dizertačnej práce, pri ktorých bolo ciel'om overit funkčnost' pripraveného výskumného nástroja a jeho prípadné úpravy, ak by sa ukázali ako potrebné. Adekvátne k tomu sme použili otvorené kódovanie. Prezentované výsledky sú výstupmi z určitej etapy našej práce, ale aj napriek tomu ich považujeme za dostatočné na prvotné zachytenie toho ako ovplyvňuje šport život osôb so zdravotným znevýhodnením.

Pri tvorbe výskumnej vzorky bol použitý zámerný výber. Ako uvádza Tomšik (2017) v zámernom výbere si výskumník sám určí znaky, podl'a ktorých si následne volí respondentov. Avšak tieto znaky musia byt' relevantné pre daný typ výskumu. Medzi tieto znaky môžeme zaradit' určitú vlastnost' alebo stav. To znamená, že na základe týchto kritérií sú cielene vyhl'adávané osoby, ktoré tieto kritéria spĺñajú a zároveň sú ochotné sa na výskumnom skúmaní podielatat.

Výskumnú vzorku tvorilo 5 osôb so zdravotným znevýhodnením, ktoré sa aktívne venujú športovej činnosti. Výskumu sa zúčastnili 2 ženy a 3 muži vo veku od 18 do 35 rokov. Išlo o osoby so zdravotným znevýhodnením, ktoré športujú na profesionálnej úrovni.

Zber dát prebiehal vzhl'adom k aktuálnym protipandemickým opatreniam v hybridnej forme, osobným stretnutím alebo v online priestore. Na začiatku rozhovoru som si od respondentov vyžiadala súhlas k zostaveniu audionahrávky, následne z ktorých bol zostavený doslovný prepis.

\section{Výsledky}

Šport je pre ludí so zdravotným postihnutím významným prostriedkom rehabilitácie, readaptácie, resocializácie, integrácie až inklúzie. Sociálne vzt́ahy počas športovej činnosti sú predpokladom pre prekonanie sociálnych, názorových, náboženských a rasových predsudkov. Prostredníctvom interakcie s intaktnými športovcami sa budujú a udržujú sociálne vzt'ahy a kompenzujú sa dôsledky zdravotného postihnutia.

\section{Reflektovanie prínosov športu do života človeka so zdravotným znevýhodnením}

Športová činnost́človeku napomáha k udržaniu telesnej, ale aj duševnej zdatnosti a zdravia a môže sa stat' novým životným štýlom v živote človeka. Motivácia k zapojeniu sa do športovej činnosti môže bytt rôzna. Za jeden z klúčových rozdielov považujeme práve vplyv rodiny. „šport pre mňa znamená strašne vel'a, nakol'ko som od malička pri športe vyrastal, nakol'ko môj otec aktívne hrával futbal, čiže šport bol od malička súčastou môjho života a vždy som túžil a chcel som ho robit' a som rád, že sa mi to nakoniec podarilo (Š1). Na porovnanie športovkyňa 3 mala z rodinného prostredia inú skúsenost:́ „,šport sa v našej rodine nikdy neobjavoval, moji rodičia sú skôr gaučové typy (smiech). Až ked’som sa na liečení stretla s jedným kamarátom a rozprával mi o boccii rozhodla som sa to skúsit"'(AS Š̉). Vel'kú úlohu zohrávajú aj média. Športovec 2 pravidelne sledoval paraolympiádu, čo ho priviedlo k myšlienke, že by to mohol skúsitt. „Pravidelne som v telke sledoval rôzne podujatia kde vystupovali športovci so zdravotným znevýhodnením a vždy som sa tešil na paraolympiádu. Už od malička som sníval, že raz tam budem aj ja. Doma ma odhovárali, triedna hovorila, že na to nemám, kamaráti sa smiali, že som blázon. A to bola tá najuäčšia motivácia dokázat' to"(Š2).

Pocity, ktoré sa športovcom so zdravotným znevýhodnením spájajú so športom sú rôzne. „Pocitov, ktoré sa mi spájajú so športom je pfú, vela. V prvom rade je to určite radost', vd’ačnost’ a štastie“(AS Š5). „Tie pocity sú neskutočné. Je to obrouská radost', neopísatel'ná vd’ačnost', aj ked'som často unavená, vd’aka športu som naozaj štastná" (AS Š3). Naopak športovcovi 4 sa pri športe vytvárajú aj negatívne pocity. Na otázku nám odpovedal: ,je to určite vd'ačnost', ale vo vel'kej miere je to stres a strach u mňa. No a naozaj vo vel'kej miere je to nervozita, lebo ja som dost́ nervózny človek v takýchto veciach. Asi je to najviac tá nervozita a potom radost" (穴4).

Vztahy medzi športovcami so zdravotným znevýhodnením sú porovnatel'né so vzt'ahmi medzi intaktnými športovcami. Vládne medzi nimi zväčša príjemná atmosféra, ktorá sa na sútaži zmení na prirodzenú sútaživost'. Športová činnost' predstavuje pre človeka so zdravotným znevýhodnením priestor na nadväzovanie nových sociálnych kontaktov a zlepšovanie sociálnych zručností. „Proǵ tréning bol zuláštny, nikoho som nepoznal, bolo to pre mňa všetko nové. Naštastie ma velimi rýchlo zobrali do partie a myslím si, že si vychádzame v tíme vel'mi dobre. Podporujeme sa, pomáhame si a hlavne mi rozumejü“(Š2). „Pfú, myslím si, že 
ako aj v bežnom živote, tak aj u nás v klube je to vel'mi individuálne. S niekým som si sadla hned', s iným časom a s pár l’ud'mi sa tolerujeme. Avšak, nemôžem povedat', že by tie vzt́ahy boli zlé" (AS Š5). Vztahahy medzi športovcami však vníma, každý športovec inak. „Noo.. podporujeme sa tak na oko, ale potom nakoniec aj tak zvít'azí tá sútaživost' a každý chce byt' ten, čo vyhrá“ (S1). Situáciu nám podobne opísal aj športovec 4 „mimo zápas sme kamaráti, pozdravíme sa, ale prídeme na ten kurt alebo zápas a ten čas sme v podstate nepriatelia, na život a na smrt'lebo si ideme si za tým vít’azstvom a vôbec a mňa osobne netrápi, že s týmto som kamarát tak ho nechám vyhrat"“(

\section{Reflektovanie rozdielov v športe medzi intaktnou častón populácie a osobami so zdravotným znevýhodnením}

Rozdiely, ktoré môžeme pozorovat' pri možnostiach intaktných občanov a u l'udí so zdravotným znevýhodnením majú vplyv na procesy spojené so socializáciou. Ak sa bližšie pozrieme na výber aktivít, ktoré majú osoby so zdravotným znevýhodnením, tieto aktivity sú značne obmedzené nakol'ko môže vyberat́len športové činnosti, ktoré spĺnajú určité podmienky. „Od malička som chcel športovat', avšak u nás na dedine bolo možné hrat'len futbal a to sa vzhl'adom k tomu, že som pripútaný na vozík nedalo“ (Š1). Podobnú skúsenost' má aj športovkyňa 3: „moje kamarátky so sídliska chodili na rôzne športové krúžky a ja som mohla chodit'len na tie kreatívne, aj ked'ma nebavili. Žial', moji rodičia museli uybrat'to, kde boli ochotný ma zobrat"“ (AS Š3). Tieto skúsenosti môžu byt' zapríčinené najmä faktom, že športovísk s bezbariérovým prístupom sú stále dostupné iba v minimálnej miere a osoby so zdravotným znevýhodnením sa na športovisko či štadión dostanú iba za pomoci druhej osoby. „Pre človeka na invalidnom vozíku je skoro ažnereálne íst' na nejaký zápas bez doprovodu. Je pre nás t’ažké užívat' si šport v pasívnej forme a to ešte nehovorím o tej aktívnej. Športu sa venujem viac ako 5 rokov, ale športovísk kde by som mohol trávit́ čas a zlepšovat' sa je vel'mi málo a žiadne nepribúdajú“ (Š2). Podobnú skúsenost' so športoviskami má aj športovkyňa 5: „je mi smutno ked” vidím ako pribúdajú nové ihriská, opravujú sa tie staré a architekti stále nemyslia na handicapované deti. Pritom by stačilo pár jednoduchých úprav a mohli by sa hrat' všetky spolu“ (AS Š5).

Osoby so zdravotným znevýhodnením trávia svoj vol'ný čas rovnakým spôsobom ako intaktné osoby. Respondenti sa zhodli na tom, že odkedy sa začali venovat' športovej činnosti, trávenie ich volného času sa zmenilo a ovela viac času venujú práve trénovaniu. „Vo vol'nom čase chodím von s kamarátkami, počúvam hudbu, ale najčastejšie športujem. Trénujem doma, trénujem vonku a to je pre mňa najlepšie strávený volný čas“(AS Š3). „Ja naozaj toho vol'ného času moc nemám, chodím do školy, príprava a všetko ostatné mi zaberie viac času ako mojím spolužiakom. Ale všetok vol’ný čas, ktorý mám venujem športu. Nakol'ko tréning prebiehajú v Bratislave len cesta autom mi zaberie dost' čas a v telocvični cez víkendy s mamou trávime celé hodiny. Je to pre mňa relax" (Š2).

Prostredníctvom športu majú osoby so zdravotným znevýhodnením priestor na sebarealizáciu a na aktívne vyplnenie vol'ného času. Práve vd’aka športu netrávia čas v izolácii a je im vytvorený priestor na rozvíjanie telesných, psychických, ale najmä sociálnych zručností. Túto skutočnost́ nám potvrdil aj športovec 4: „Kým som sa nevenoval športu, trávil som čas doma sám, hrával som hry na internete a celé hodiny pozeral televízor. Nemal som kamarátov, cítil som sa sám, ale nevedel som to zmenit. Práve vd’aka športu mám dnes kamarátov, ktorí mi rozumejú a už netrávim celé dni sám. Hocikedy sa dohodneme a ideme spolu trénovat' a vždy sa tam vel'mi nasmejeme. Už by som nechcel žit život ako dovtedy“ (Š́4).

\section{Reflektovanie športu ako významného nástroja procesu inklúzie}

Za dôležitý predpoklad úspešnosti inklúzie prostredníctvom športovej činnosti môžeme považovat' práve spoluprácu medzi športovcami so zdravotným znevýhodnením s intaktnými športovcami. Ako sme už spomínali počas športovej činnosti vznikajú viaceré interakčné procesy, pričom z jedným z tých najdôležitejších je práve vzțah športovca s osobným asistentom. Osobný asistent zohráva dôležitú úlohu pri samotnej realizácii športovej aktivity. Ako uvádzajú naši respondenti, bez pomoci osobného asistenta by sa športu venovat' nemohli. „Hrám bocciu a v tomto športe je asistent vel’mi dôležitý. Podáva mi loptičky, nosí mi

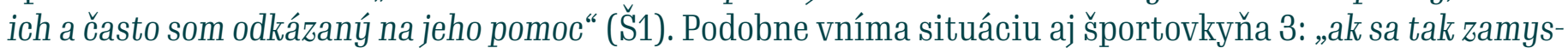
lím, bez asistenta by som neurobila nič. Asistenti naozaj plnia dôležitú úlohu a dovolím si povedat', že vd’aka ním môžeme športovat" (AS Š3). Osobných asistentov v športe robia najčastejšie rodinní príslušníci, nakol’ko nie je záujem širšej verejnosti a vykonávanie športového asistenta. Športovci so zdravotným znevýhodnením by uvítali väčšiu pomoc od štátu pri podporovaní, ale hlavne vytvorení pozície športového asistenta. 
„V športe chýba športový asistent, je to smutné, že to musia robitt rodinní príslušníci. Ak by bola vytvorená takáto pozícia, uvítali by to športovci, ale aj ich rodičia“ (AS Š5). Podl'a nášho názoru by športový asistent vytvoril väčší priestor pre začlenenie človeka so zdravotným znevýhodnením do spoločnosti. Podporilo by to inkluzívny potenciál, ktorý v sebe šport má. Prišlo by k prepojeniu osôb so zdravotným znevýhodnením a človekom bez neho.

Športovci so zdravotným znevýhodnením by uvítali športové podujatie, na ktorom by mali možnost' stretnút' sa s intaktnými športovcami. Ako uvádzajú naši informanti, takéto stretnutie by pomohlo k tomu, aby sa l'udom rozšírili obzory a mohlo by pomôct' k odstráneniu predsudkov. „Určite by som to uvítal, bola by to jedna z možností ako zdravému človeku ukázat', že aj človek so zdravotným znevýhodnením vie niečo v živote robit" (Š́1). Podobne na otázku odpovedal aj športovec 4: „, Takéto podujatie by pomohlo odbúrat' predsudky spoločnosti“ (Š́4).

Na otázku sme však dostali aj negatívnu odpoved’” „sama viem ako nás liudia vnímajú, každý víkend sledujem v telke futbalový zápas a keby len jeden, hned'niekol'ko. Celé Slovensko žilo olympiádou a majstrovstvami v hokeji ani nehovorím. Nechcem tým povedat', že je to zle. Ale uvedomili ste si niekto, kol'ko prenosov bolo z paraolympiády? Bolo to smiešne, už ked'konečne mali dávat' online prenos z boccie, kde sa hralo o zlato, tak nestihli začiatok. A úprimne si povedzme, ako by reagovali diváci keby nestihnú začiatok zápasu Slovana? Možno by podujatie, kde by sme sa stretli my handicapovaní a zdraví športovci bolo zaujímavé, ale voči búraniu predsudkov som skeptická“ (AS Š5).

\section{Diskusia}

Prezentované výsledky nášho výskumu signalizujú, že šport zastáva významné miesto pri začleňovaní osôb so zdravotným znevýhodnením do spoločnosti. Aj napriek pozitívnym výsledkom výskumu zastávame názor, že športu zdravotne znevýhodnených osôb sa v spoločnosti nedostáva adekvátne miesto a jeho účinky by mohli bytt ešte výraznejšie. K podobným záverom prišli aj autori Kitchin a Howe (2014), podla ktorých skutočná integrácia v rámci športového procesu ešte stále nie je realizovaná. Túto skutočnost' sa nám podarilo preukázat' aj v našom výskume, nakol'ko naši informanti trávia počas športových aktivít čas najmä s osobami so zdravotným znevýhodnením a chýba prepojenie s intaktnou častó populácie.

L'udia so zdravotným znevýhodnením v komparácií s l'ud’mi bez zdravotného postihnutia disponujú rovnakými výsledkami v oblasti realizácie športových aktivít. Obe skupiny spoločnosti chápu šport ako spôsob nadväzovania nových kontaktov, skvalitnenia životného štýlu a kondície a istú aktivitu prostredníctvom, ktorej dokážu odbúrat' stres. Jednoduchým spôsobom môžeme pokladat'za fakt, že šport pre l'udí so zdravotným postihnutím poskytuje socializáciu a možnost' zachovania rovnováhy v spoločnosti (Dowling a kol., 2012).

Autori Wilhite, Mushett a kol. (1997) poukazujú na skutočnost', že l’udia so zdravotným znevýhodnením sa stretávajú s viacerými obmedzeniami pri možnostiach trávenia voĺného času. Podobné výsledky vyšli aj v našom výskume, pri ktorom sme zdôraznili nedostatočný počet športovísk, ktoré by boli prispôsobené pre osoby so zdravotným znevýhodnením. Autori vo svojej výskumnej štúdií konštatujú, že osoby so zdravotným znevýhodnením nepovažujú za prioritné trávit’ svoj voliný čas s rovesníkmi bez zdravotného znevýhodnenia. Vel'mi dôležitou výzvou pri realizácí športových aktivít pre l'udí so zdravotným znevýhodnením je diferenciálna hodnota, ktorú majoritná spoločnost́ kladie na tieto skúsenosti. Postoj vo vzt'ahu k sútaživosti človeka so zdravotným znevýhodnením a majoritnej spoločnosti môžeme vnímat́ prostredníctvom médií. Propagácia výkonu športovej aktivity je zväčša súčastóou majoritnej populácie (Evans, 2004).

Na základe našich informantov konštatujeme, že šport zastáva významné miesto v procese začleňovania osôb so zdravotným znevýhodnením, avšak je potrebné, aby sa danej problematike venovalo viac pozornosti. Začlenenie osôb so zdravotným znevýhodnením prostredníctvom športovej činnosti, môže byt' prospešné pre účastníkov, odborníkov z praxe a tvorcov politík, ako aj pre futbalové kluby a komunity, ktorým slúžia (Tacon, 2017).

\section{Záver}

Športovú činnost' právom môžeme chápat́ ako jednu z popredných foriem inklúzie osôb so zdravotným znevýhodnením do spoločnosti. Ked’ sa človek ocitne v sociálnej exklúzii, trpí nedostatkom kontaktov a nemá možnost' rozvíjat' svoje sociálne zručnosti. Pre osoby so zdravotným znevýhodnením vytvára športová 
činnost' priestor pre stretávanie, vymieňanie skúseností, ale taktiež sa prostredníctvom nej učia vyrovnávat' sa s prekážkami. Súčasný stav športovísk však bráni aktivitám l'udom so zdravotným znevýhodnením. So skúseností vieme konštatovat', že l'udia so zdravotným znevýhodnením, ktorí sa venujú športovej činnosti majú väčšiu šancu zamestnat' sa, založit' si rodiny aj s intaktnými partnermi. Vd’aka športu sa môžu zapájat' do spoločenského života a zarobit’ si na seba. Aj vd’aka tomu môžu časom zabudnút aj na svoje postihnutie.

\section{Literatúra}

Dovalil, J. a kol. (2004). Olympismus. Praha: Olympia.

Dowling, S. et. al. (2012). Promoting social inclusion through Unified Sports for youth with intellectual disabilities: a five-nation study. Journal of Intellectual Disabillity Research. 50(10), 923-935. https:// doi.org/10.1111/j.1365-2788.2012.01587.x.

Evans, G. - Phyllida, S. (2004). The contribution of culture to regeneration in the UK: a review of evidence: a report to the Department for Culture Media and Sport. http://repository.londonmet.ac.uk/6109/1/EvansShaw2004.pdf.

Hall, Lindzey (1997). Psychológia osobnosti. Bratislava: SPN-Mladé letá.

Haudenhuyse. (2017). Social Science Open Access: Introduction to the issue „sport for social inclusion: questioning policy, practice and research Social inclusion. 5(2), 85-90.10.17645/si.v5i2.1068

Hrouda, T., Rybová , L. (2010). Sport v životní dráze člověka s tělesným postițením. Aplikované pohybové aktivity $v$ teorii a praxi.1(1), 56-61.

Kitchin, P. J., Howe, D. (2014) The mainstreaming of disability cricket in England and Wales: Integration ‘One Game’ at a time. Sport Management Review, 17(1), 65-77. https://doi.org/10.1016/j.smr.2013.05.003.

Magee, J. - Jeanes, R. et. al. (2018). „Yes we are inclusive“: Examining provision for young people with disabilities in community sport clubs. Sport Management Review, 21(1), 38-50. https://doi.org/10.1016/j. smr.2017.04.001.

Mcconkey, R. et. al. (2019). The Meaning of Social Inclusion to Players With and Without Intellectual Disability in Unified Sports Teams. Inclusion, 7(4), 234-243. https://doi.org/10.1352/2326-6988-7.4.234.

Qi, J. - Ching Ha , A, S. (2012). Hong Kong Physical Education Teachers' Beliefs about Teaching Students with Disabilities: A Qualitative Analysis. Asian social science, 8(8), 911-2017. 10,5539/zad.v8n8p3

Sekot, A. (2007). Sociologický pohled na sport: Konceptuální východiska. Česká kinantropologie Praha: Česká kínantropologická společnost, 11(1), 53-61. Tacon, R. (2017). Football and social inclusion: Evaluating social policy. Managing Leisure: An International Journal, available. 12(1), 1-23. http://dx. doi.org/10.1080/13606710601056422.

Tomšík, R. (2017). Kvantitatívny výskum v pedagogických vedách. Nitra: Pedagogická fakulta, Univerzita Konštantína a Filozofa v Nitre.

Wilhite, B. , Mushett, C. A. et. al. (1997) Promoting inclusive sport and leisure participation: Evaluation of the Paralympic Day in the schools model. Adapted Physical Activity Quarterly, 14(2), 131-146. : https:// doi.org/10.1123/apaq.14.21.131.

\section{Informácie o autoroch}

\section{Mgr. Erika Štangová}

Som interná doktorandka na Fakulte sociálnych vied Univerzity sv. Cyrila a Metoda v Trnave. Vo svojej dizertačnej práci sa venujem významu športu ako prostriedku inklúzie u osôb so zdravotným znevýhodnením.

Email: stangova1@ucm.sk 